\title{
Definition of vitamin D deficiency in schoolchildren: systematic review with meta-analysis
}

\author{
Marcela Almeida LINDEN, Renata Germano Borges de Oliveira Nascimento FREITAS, Gabriel HESSEL, \\ Denise Barbieri MARMO and Maria Ângela BELLOMO-BRANDÃO
}

Received 12/4/2019 Accepted 12/9/2019

ABSTRACT - Background - Vitamin D deficiency is being recognized as a pandemic due to the volume of people affected by the deficiency and the number of illnesses generated or stimulated by the deficiency. There is a lack of consensus in the literature on what is considered vitamin $\mathrm{D}$ deficiency $[25(\mathrm{OH})$ D]. Objective - This review brings together the most common levels of $25(\mathrm{OH}) \mathrm{D}$ found in healthy schoolchildren and what is considered deficient. Methods - This systematic review was based on the literature accessed from the electronic databases: MEDLINE, EMBASE, LILACS, SCOPUS and WEB OF SCIENCE. The following descriptors were used in English, Portuguese and Spanish: "Vitamin D"; "Vitamin D deficiency"; "Nutritional Supplements" as well as all their synonyms. The meta-analysis was performed considering the random model. Inclusion criteria: healthy children aged 6 to 12 years, studies that had vitamin D levels, defined vitamin D deficiency. Results - Of the 191 potentially eligible articles, only six articles were included, with 2618 students in total. The mean value of $25(\mathrm{OH}) \mathrm{D}$ was estimated at $18.11 \mathrm{ng} / \mathrm{mL}$ with $95 \%$ confidence interval. Among the articles found, three were considered deficiency levels below $20 \mathrm{ng} / \mathrm{mL}$, one considered below $18 \mathrm{ng} / \mathrm{mL}$, another below $15 \mathrm{ng} / \mathrm{mL}$, and the latter below $11 \mathrm{ng} / \mathrm{mL}$. The prevalence of vitamin D deficiency among the articles was 48.6\%, 7\%, 98\%, 64.63\%, 19.5\%, 28.4\%, according to each classification used by the same. Conclusion - The most common definition in the literature of $25(\mathrm{OH}) \mathrm{D}$ deficiency in schoolchildren was at levels below $20 \mathrm{ng} / \mathrm{mL}$. No side effects have been reported in studies that used fortification and/or vitamin D supplementation. Daily supplementation is more effective than seasonal supplementation. However, more studies are needed to define what can be considered as optimal levels of 25(OH)D in children.

HEADINGS - Vitamin D. Avitaminosis. Child. Dietary Supplements. Review.

\section{INTRODUCTION}

Vitamin $\mathrm{D}$ deficiency is being recognized as a pandemic because of the volume of people affected by deficiency and the number of diseases generated or stimulated by such a deficiency ${ }^{(1)}$. Vitamin $\mathrm{D}$ deficiency is reported worldwide, where an estimated 1 billion people have vitamin D deficiency or insufficiency ${ }^{(2,3)}$. Therefore, interest in vitamin D has increased considerably in recent years among health professionals, the media and the public.

Vitamins are essential organic compounds that cannot be synthesized by the human body and must be ingested ${ }^{(4)}$. The term vitamin D refers to vitamin D2 (ergosterol) and/or vitamin D3 (cholecalciferol), since they are the most abundant and active versions. Vitamin D2 and vitamin D3 are types of dry steroids, that is, steroids that suffer a break between their two chemical rings ${ }^{(5)}$. Vitamin D2 is not produced in the body but obtained through diet. Vitamin D3 is the conventional definition of a vitamin, which can now be defined as a pre-hormone because it is produced by the body. Differences between the two versions can be seen in the presence of a double bond between carbons 22 and 23, and a methyl group on carbon 24 of vitamin $\mathrm{D} 2^{(6-8)}$.

Vitamin D was identified in the early 20th century and was initially considered as a nutrient. It has now been classified as a hor- mone due to its regulation of calcium and phosphorus metabolism along with parathyroid hormone ${ }^{(9)}$. Since vitamin $\mathrm{D}$ deficiency can cause rickets and osteomalacia, this vitamin is therefore essential for the maintenance of bone health of children and adults ${ }^{(10-11)}$.

The 25-hydroxyvitamin D $(25[\mathrm{OH}] \mathrm{D})$ is the most abundant metabolite and the best indicator for the evaluation of vitamin D status. Low levels of $25(\mathrm{OH}) \mathrm{D}$ are associated with several factors such as skin pigmentation, use of sunscreen, clothing, latitude, season of the year, air pollution, decreased intake of food source, malabsorption syndrome, obesity, withdrawal from sun exposure, pregnancy, age, renal or hepatic failure ${ }^{(12,13)}$.

In children and adolescents, $25(\mathrm{OH}) \mathrm{D}$ blood levels are being associated with the prevention of diseases related to the immune system (asthma, diabetes mellitus type 1), infectious diseases (respiratory infections, influenza) and cardiometabolic markers ${ }^{(2,14)}$. In order to prevent hypovitaminosis D, the Institute of Medicine (IOM) increased the vitamin D recommendation by establishing a Recommended Dietary Allowance value of 400 IU/day for the first year of life, and $600 \mathrm{IU} /$ day for children 1 to 18 years of age $\mathrm{e}^{(15)}$. The IOM, after reviewing the literature, concluded that 25(OH)D levels of $20 \mathrm{ng} / \mathrm{mL}$ meet the requirements of at least $97.5 \%$ of the population in all age groups. They also concluded that a consensus is needed at cut-off points for serum inadequacy of $25(\mathrm{OH}) \mathrm{D}$ in

Declared conflict of interest of all authors: none

Disclosure of funding: no funding received

Universidade Estadual de Campinas (UNICAMP), Campinas, SP, Brasil.

Corresponding author: Marcela Almeida Linden. E-mail: marcelalinden@hotmail.com 
order to avoid problems of under-treatment or excessive treatment for hypovitaminosis $\mathrm{D}^{(16)}$. Despite the IOM's pronouncement, there is still a divergence among published studies in relation to the values used to identify vitamin D deficiency.

The European Society of Pediatric Gastroenterology, Hepatology and Nutrition (ESPGHAN), recommended for scientific and clinical purposes to practice using $25(\mathrm{OH}) \mathrm{D}>20 \mathrm{ng} / \mathrm{mL}$ as the standard for sufficiency, and $<10 \mathrm{ng} / \mathrm{mL}$ as severe deficiency ${ }^{(17)}$.

There is a lack of consensus in the literature regarding what is considered a deficient level of 25(OH)D. Maintaining normal levels of vitamin D is important for the growth and development of bones in these children. Thus, the present review aimed to bring together the studies conducted with children between 6 and 12 years of age, schoolchildren by definition, to define what the studies considered as a deficient level of $25(\mathrm{OH}) \mathrm{D}$.

\section{METHODS}

A systematic review of the literature was done in the electronic databases MEDLINE, EMBASE, LILACS, SCOPUS and WEB OF SCIENCE. The descriptors were chosen according to the search performed in the DeCS (BIREME health science descriptors). The following descriptors were used in English, Portuguese and Spanish: "Vitamin D"; "Vitamin D deficiency"; "Nutritional Supplements", as well as all their synonyms found in the MeSH (Medical Subject Headings) search for the PUBMED portal; and Emtree for EMBASE. The Boolean operators used were "AND" and "OR" for a combination of descriptors and terms used to track publications. Inclusion criteria were: 1) studies performed with children in the aged 6-12 years, because it is a group with greater homogeneity; 2) studies with healthy children; 3) studies that had vitamin D levels and defined vitamin D deficiency; Exclusion criteria: review studies, theses and dissertations, animal studies, and studies where the age group was not within the limits sought.

The only limit used in the database search was age (school children). All other exclusion criteria have been established for each article by reading the title and abstract. Articles were not limited by their year of publication or language.

The searches in the databases were carried out from September to November of 2018, the study was carried out by two independent reviewers, and after exclusion of the articles according to the defined criteria the two reviewers shared their findings.

The systematic review, in order to be developed, followed the standards recommended by the PRISMA model (Main Items for Reporting Systematic Reviews and Meta-analyses) ${ }^{(18)}$. The metaanalysis to estimate the mean and standard deviation of vitamin $\mathrm{D}$ in children was performed considering the random model. The confidence interval was $95 \%$. We had considered levels of $25(\mathrm{OH})$ $\mathrm{D}$ before supplementation for meta-analysis. We used the computer program: R version 3.3.1. Copyright (C) 2016 The R Foundation for Statistical Computing Metafor Package 1.9-9, to perform the analysis.

\section{RESULTS}

Through this search, 191 potentially eligible articles were initially found (MEDLINE $=26$, EMBASE $=10$, LILACS $=3$, SCOPUS=142 and WEB OF SCIENCE=10). Of these 191 articles, 20 were excluded as duplicates between the databases. After reading the titles and abstracts, 159 articles were excluded, where the theme was not relevant, and/or the age range of the study did not match our inclusion criteria. For full reading, 12 articles were selected and only six articles met all the inclusion criteria. No articles were excluded by year of publication or language (FIGURE 1).

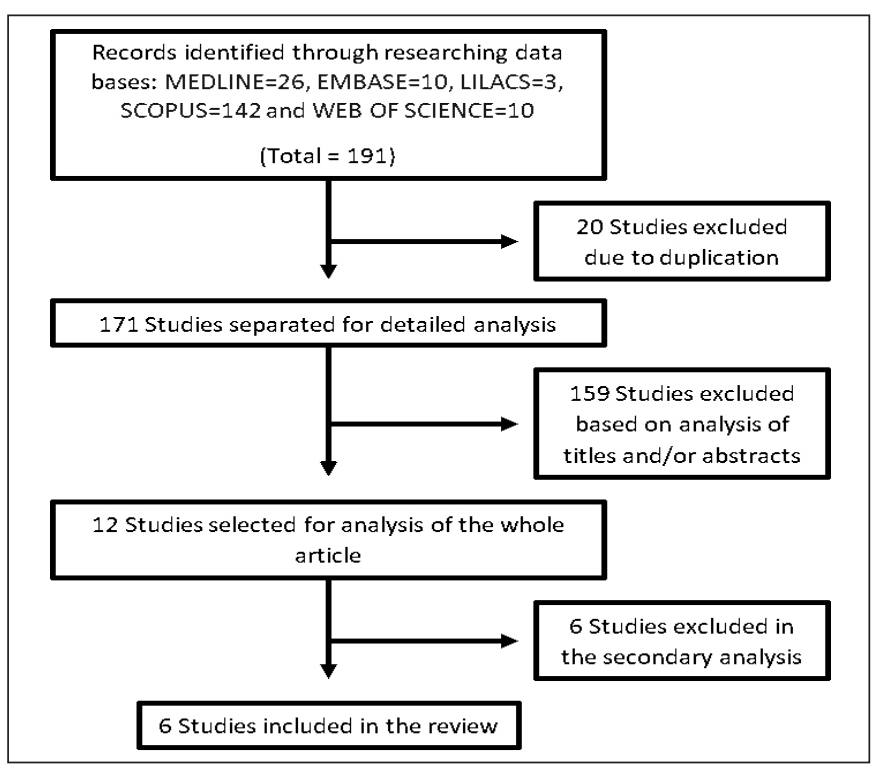

FIGURE 1. Flowchart review of the findings in the database.

The reviewed articles differ in some respects such as the serum $25(\mathrm{OH}) \mathrm{D}$ values considered to be deficient, insufficient or adequate. Three of the six articles considered deficiency as levels below $20 \mathrm{ng} /$ $\mathrm{mL}^{(19-21)}$, one considered it as below $18 \mathrm{ng} / \mathrm{mL}^{(22)}$, another below 15 $\mathrm{ng} / \mathrm{mL}^{(23)}$, and the latter below $11 \mathrm{ng} / \mathrm{mL}^{(24)}$. Therefore, half of the studies analyzed considered deficiency as below $20 \mathrm{ng} / \mathrm{mL}$.

In the articles, we found a high prevalence of vitamin d deficiency. If we consider the most common value cited as vitamin $\mathrm{D}$ deficiency $(<20 \mathrm{ng} / \mathrm{mL})$, the number of children within the deficiency increases considerably as shown in FIGURE 2.

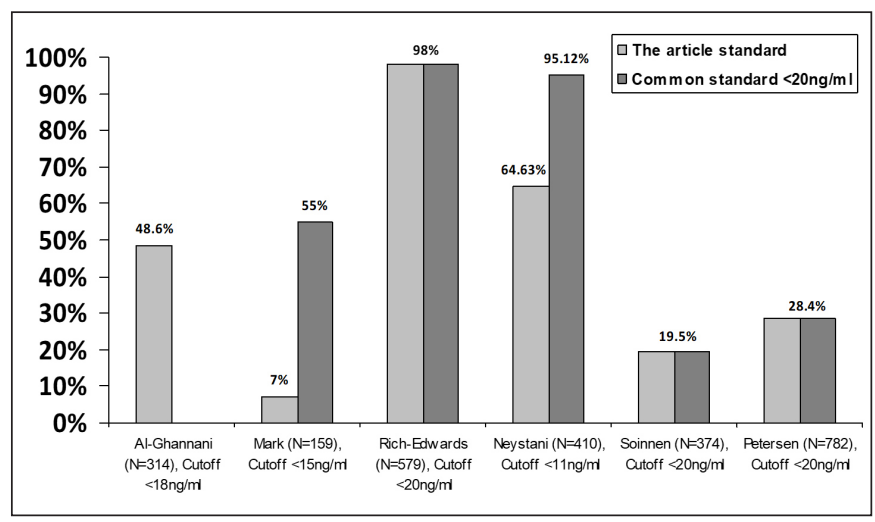

FIGURE 2. Prevalence of vitamin D deficiency between articles before intervention.

Al-Ghannani article did not specifically describe the number of children with vitamin D levels below $20 \mathrm{ng} / \mathrm{mL}$

Among the studies that offered vitamin D by fortified foods and/or by oral supplements, the dosage offered ranged from 100 IU to $300 \mathrm{IU} /$ day. One study performed seasonal supplementation of 13,700 IU over seven days (TABLE 1). None of the studies reported side effects during supplementation ${ }^{(19-24)}$. 
TABLE 1. Main data of the articles selected for the systematic review.

\begin{tabular}{|c|c|c|c|c|c|c|c|}
\hline Reference & Population & Age & Study objective & Type of study & Type of intervention & $\begin{array}{l}\text { Reference } \\
\text { value used }\end{array}$ & Results \\
\hline $\begin{array}{l}\text { Mark et al., } \\
2011^{(24)}\end{array}$ & $\begin{array}{l}159 \\
\text { Canadian } \\
\text { children of } \\
\text { both sexes. }\end{array}$ & $8-11$ years & $\begin{array}{l}\text { To describe the } \\
\text { modifiable correlates } \\
\text { of vitamin D status in } \\
\text { youth; including intake } \\
\text { of vitamin D food } \\
\text { sources, supplements, } \\
\text { physical activity and } \\
\text { adiposity. }\end{array}$ & Prospective & $\begin{array}{l}\text { A 24-hour food recall for } 3 \\
\text { days was used to evaluate the } \\
\text { consumption of Vitamin D by } \\
\text { diet and supplementation. }\end{array}$ & $15 \mathrm{ng} / \mathrm{mL}$ & $\begin{array}{l}\text { Vitamin D intake was below current } \\
\text { recommendations, with } 45 \% \text { of youths } \\
\text { having } 25(\mathrm{OH}) \mathrm{D} \text { levels below } 20 \mathrm{ng} / \mathrm{mL} \text {; } \\
\text { Greater physical activity showed an increase } \\
\text { of } 0.84 \mathrm{ng} / \mathrm{mL} \text { of } 25(\mathrm{OH}) \mathrm{D} \text {. } \\
\text { They believe it is unlikely that increased milk } \\
\text { consumption or increased physical activity } \\
\text { (outdoors) would increase vitamin D enough } \\
\text { to reach sufficient levels of } 25(\mathrm{OH}) \mathrm{D} \text { in } \\
\text { Canadian youth. }\end{array}$ \\
\hline
\end{tabular}

Duration of 49 days.

\begin{tabular}{|c|c|c|c|}
\hline $\begin{array}{l}\text { Rich- } \\
\text { Edwards et } \\
\text { al., } 2011^{(20)}\end{array}$ & $\begin{array}{l}579 \\
\text { Mongolian } \\
\text { children of } \\
\text { both sexes. }\end{array}$ & $9-11$ years & $\begin{array}{l}\text { To verify if daily } \\
\text { supplementation of } \\
\text { vitamin } \mathrm{D} \text { would } \\
\text { be more effective } \\
\text { than seasonal } \\
\text { supplementation }\end{array}$ \\
\hline
\end{tabular}

Group with ordinary milk - 710

$\mathrm{mL} /$ day.

Group with US fortified milk -

$710 \mathrm{~mL} /$ day containing $300 \mathrm{IU}$

of vitamin D.

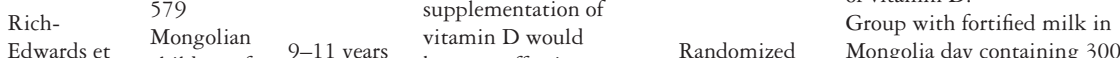

Edwards et Mongr

Randomized Mongolia day containing 300

IU of vitamin D.

Group with vitamin D

supplementation of $300 \mathrm{IU}$

daily.

Group with seasonal vitamin D

supplementation - $13700 \mathrm{IU}$

after 7 days.

Duration of 12 weeks.

Group with pure milk.

Group with fortified milk (100

IU of vitamin D and $500 \mathrm{mg}$ of
To compare the

effectiveness of vitamin

Neyestan et 410 Iranian

al., 2014 (25) children of 9-12 years

both sexes.
$\mathrm{D}$ fortification in milk

supplementation in

primary school children.
Randomized

double blind

calcium per $200 \mathrm{~mL}$ package).

Group with pure orange juice.

Group with fortified orange

juice (100 IU of vitamin D and

$500 \mathrm{mg}$ of calcium per $200 \mathrm{~mL}$

package).

Group with supplement (200

$\mathrm{IU}$ of vitamin D and $500 \mathrm{mg}$ of

calcium).

Placebo group.
Duration of 12 weeks.

Control group with normal

meals.

Group with fish oil ( $403 \mathrm{mg}$ of
Of the children who received seasonal supplementation after 49 days, $98 \%$ were still with low levels of vitamin D compared to $41 \%$ in those receiving daily supplementation or fortified milk.

$20 \mathrm{ng} / \mathrm{mL} \quad$ The impact of supplementation was greater in those who started with lower baseline vitamin D levels.

Supplementation with $300 \mathrm{IU} /$ day of vitamin $\mathrm{D}$ was not able to remove the children from the deficiency; it was suggested that larger daily doses are necessary.

$\begin{array}{lll}\text { Al- } & \begin{array}{l}314 \\ \text { children of }\end{array} \quad 9-10 \text { years } \\ \text { Ghannami et } \\ \text { al., 2016 }\end{array} \quad \begin{aligned} & \text { Oman of } \\ & \text { both sexes. }\end{aligned}$

(EPA) supplementation
by fish oil in children.
DHA and $53 \mathrm{mg}$ of EPA).
Group with a meal containing
$100 \mathrm{~g}$ of grouper, snapper,
kingfisher, emperor or anchovy
fish (having 150 to $200 \mathrm{mg}$ of omega-3).
Randomized the fish-based menu with docosahexaenoic acid (DHA) and by fish oil in children.
782 Danish To assess vitamin

$\begin{array}{ll}782 \text { Danish } & \\ \text { Petersen et } & \text { D status and its }\end{array}$

al., 2016 $\quad$ children of determinants in children Randomized

in the fall period.
A 24-hour food recall for 7 days was carried out to evaluate the consumption of food sources of vitamin D.
To investigate the

distribution and serum
$25(\mathrm{OH}) \mathrm{D}$ levels, and both sexes.
Soininen et 374 Finnish

al., 2016 (22) children of 6-8 years risk factors for low levels Prospective

$(<20 \mathrm{ng} / \mathrm{mL})$ of $25(\mathrm{OH})$

$\mathrm{D}$ in Finnish children.
A 4-day dietary recall was used to evaluate the quality of $20 \mathrm{ng} / \mathrm{mL}$ the diet.
After 12 weeks, supplementation with 200 IU of vitamin D and $500 \mathrm{mg}$ of calcium was more effective in increasing $25(\mathrm{OH}) \mathrm{D}$ levels and in suppressing the seasonal increase in bone-specific alkaline phosphatase. However, it was not verified that the intervention contributed to the increase of osteocalcin or reduction of parathormone.

Consumption of $200 \mathrm{IU} /$ day via supplement or $100 \mathrm{IU} /$ day via food fortification was not effective to protect $\mathrm{D}$ hypovitaminosis.
In children who received fish oil or a fish meal, the vitamin D value was higher than in the control group.

Only $7.3 \%$ of boys and $0.6 \%$ of girls had $18 \mathrm{ng} / \mathrm{mL} \quad$ sufficient levels of $25(\mathrm{OH}) \mathrm{D}>30 \mathrm{ng} / \mathrm{mL}$ There is an urgent need for a well-thought program that incorporates a food and beverage fortification and outdoor activities to help address this public health problem.

The large number of children (28.4\%) with vitamin D deficiency $(25(\mathrm{OH}) \mathrm{D}<20 \mathrm{ng} / \mathrm{mL})$ is a concern.

The use of vitamin D supplements $3 \mathrm{~d} / 7 \mathrm{~d}$ was $20 \mathrm{ng} / \mathrm{mL}$ associated with an increase of approximately $3.6 \mathrm{ng} / \mathrm{mL}$ of $25(\mathrm{OH}) \mathrm{D}$.

Vitamin D deficiency should not be perceived as a winter phenomenon.

The non-white ethnicity and the female gender were associated with lower $25(\mathrm{OH}) \mathrm{D}$.

$4 / 5$ of children do not consume the recommended daily amount of vitamin D. $1 / 5$ of the children had vitamin $\mathrm{D}$ deficiency $(25(\mathrm{OH}) \mathrm{D}<20 \mathrm{ng} / \mathrm{mL})$.

Fortified milk $(0.5 \mu \mathrm{g} / 100 \mathrm{~g}$ of vitamin D) was the food that contributed to the highest concentration of 25(OH)D. Next, the supplement was also a determinant for vitamin $\mathrm{D}$ intake among girls. There is a need to increase the supply of vitamin D (from foods or supplements) to children who live in places with higher latitudes. 
Statistically analyzed data were obtained from the six studies evaluated in this systematic review, with a total of 2618 children before supplementation, aged between 6 and 12 years old (TABLE 1). Considering the Q test of heterogeneity, the studies are considered heterogeneous $(P$-value $<0.0001)$ and the measurement of $\mathrm{I} 2=99.85 \%$. The mean value for $25(\mathrm{OH}) \mathrm{D}$ was estimated at $18.11 \mathrm{ng} / \mathrm{mL}$ with a $95 \%$ confidence interval of $11.90 \mathrm{ng} / \mathrm{mL}-24.31$ $\mathrm{ng} / \mathrm{mL}$, as shown in FIGURE $3^{(25)}$.

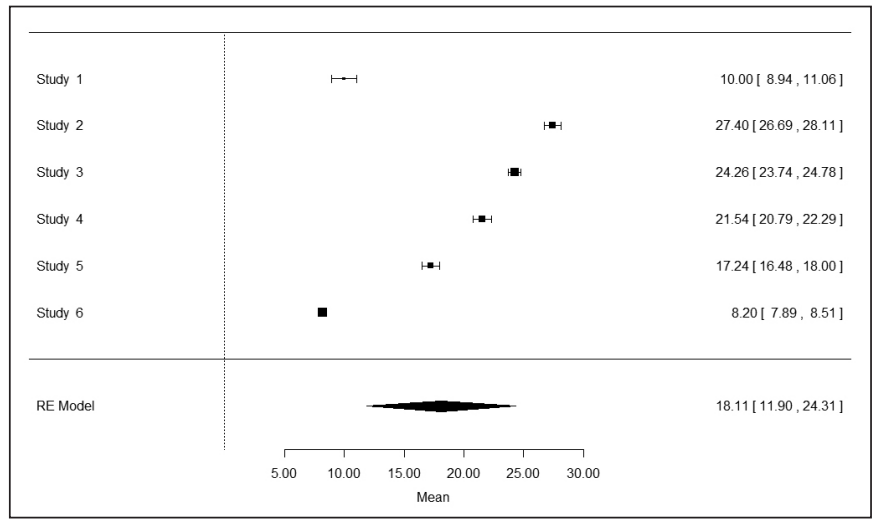

FIGURE 3. Forest plot data of values obtained for vitamin D.

\section{DISCUSSION}

The mean value of $25(\mathrm{OH}) \mathrm{D}$ in schoolchildren included in this review was estimated at $18.11 \mathrm{ng} / \mathrm{mL}$ and values below $20 \mathrm{ng} /$ $\mathrm{mL}$ define $25(\mathrm{OH}) \mathrm{D}$ deficiency in most of the studies examined, although it included different countries (e.g., Denmark, Canada, Oman, Mongolia) ethnicities, seasons, latitudes etc. It means that most children are below the recommended $25(\mathrm{OH}) \mathrm{D}$ level and need some kind of supplementation or the recommendation is not adequate.

In adults, most experts define 25(OH)D levels below $20 \mathrm{ng} /$ $\mathrm{mL}$ as deficient. One study found that when serum $25(\mathrm{OH}) \mathrm{D}$ levels increase from $20 \mathrm{ng} / \mathrm{mL}$ to $32 \mathrm{ng} / \mathrm{mL}$ the intestinal calcium absorption increases from $45 \%$ to $65 \%$. It is also known that an increase of 1,25-dihydroxyvitamin D $(1,25[\mathrm{OH}] \mathrm{D})$ results in the synthesis of cathelicidin, which is a peptide capable of killing infectious agents, thus enhancing the importance of vitamin $\mathrm{D}$ as an immunomodulator. When serum 25(OH)D levels are below 20 $\mathrm{ng} / \mathrm{mL}$, monocytes or macrophages are prevented from triggering this immune response ${ }^{(2)}$.

The reviewed articles differed in relation to the cut-off point of $25(\mathrm{OH}) \mathrm{D}$ values for the classification of vitamin $\mathrm{D}$ deficiency. However, three of the six articles analyzed considered deficiency as $25(\mathrm{OH}) \mathrm{D}$ levels were below $20 \mathrm{ng} / \mathrm{mL}$. Defining what is considered optimal levels of $25(\mathrm{OH}) \mathrm{D}$ is still a challenge for authors, as was found in this review ${ }^{(19-24)}$.

Among the studies that offered vitamin D through fortified foods and/or oral supplements, the dosage offered ranged from $100 \mathrm{IU}$ to $300 \mathrm{IU} /$ day and none of the studies indicated side effects during supplementation. The research that performed seasonal supplementation of 13,700 IU over a span of seven days also did not report any side effects ${ }^{(19-24)}$

According to the National Health and Nutrition Examination Surveys, vitamin D supplementation is a good strategy to increase vitamin D intake. Recent findings suggest that vitamin
D supplementation is more efficient for individuals who already have a high vitamin intake when compared to those with low consumption $^{(24,26,27)}$.

Moreover, according to studies with adults, the supply of vitamin D together with calcium would be a more effective strategy to raise $25(\mathrm{OH}) \mathrm{D}$ values than the supply of vitamin $\mathrm{D}$ alone $\mathrm{e}^{(21,28-30)}$. In the Neyestan et al. (2014) study, vitamin D and calcium were offered via oral supplementation and via fortification of milk and orange juice, and it was concluded that supplementation increased levels of $25(\mathrm{OH}) \mathrm{D}$, but was not effective in protecting the subjects from hypovitaminosis D. Another issue that was addressed by Neyestan et al. (2014), was the low acceptance of milk by Iranian schoolchildren. In the study with 374 Finnish children, the majority of the evaluated subjects did not consume the recommended daily amount of vitamin D; and fortified milk (20 IU/100 g of vitamin D) was the food that contributed the most to the $25(\mathrm{OH}) \mathrm{D}$ serum concentration. Next, the supplement was also determinant for vitamin $\mathrm{D}$ intake among female schoolchildren ${ }^{(24)}$.

In foods and dietary supplements, vitamin D exists as much as cholecalciferol or ergocalciferol originating from plants (vitamin D2). Vitamin D is found in a limited number of foods, such as oily fish that are known to have high amounts of the vitamin ${ }^{(31)}$. In the study by Al-Ghannami et al. (2016) where the fat-soluble vitamins in children were evaluated, fish oil supplementation and fish meal once a day for 12 weeks were used. The result was that the groups that received this omega-3 diet had better levels of $25(\mathrm{OH}) \mathrm{D}$ in relation to the control group; showing that this may be another option to use higher sources of vitamin D to enrich the diet of a population ${ }^{(22)}$.

It is known that milk is a more complete and nutritious food than the supplement, because it contains bioactive compounds and other nutrients that the supplement does not offer. However, crosssectional studies in Canada and the United States have indicated that the use of supplements has been more promising than food enrichment for the prevention of hypovitaminosis D, particularly in vulnerable winter populations ${ }^{(24,32)}$. In the study by Petersen et al. (2016) with 782 Danish children, it was observed that the frequent use of vitamin D supplements was associated with the adequacy of $25(\mathrm{OH}) \mathrm{D}$ levels (above $20 \mathrm{ng} / \mathrm{mL}$ ) in $70 \%$ of the evaluated individuals. In addition, the low intake of food sources of calcium and vitamin $\mathrm{D}$ has been reported in several countries across all age groups $^{(21,33)}$. Mark et al. (2011) applied the 24-hour recall for three days in Canadian children, and vitamin D intake was below the current Canadian recommendation ${ }^{(23)}$.

In Brazil, information about vitamin D deficiency in healthy children is still scarce. Peçanha et al. (2019) reported, in his study of 124 children with recurrent wheezing, a prevalence of vitamin $\mathrm{D}$ deficiency/insufficiency of $57.3 \%$. Similar values were found by Peracchi et al. (2014) studying children and adolescents with recurrent systemic lupus where the prevalence was $50 \%$, but when compared with a control group, deficiency was found only among $20 \%$ of them. This shows us that such values may have been influenced by the underlying disease. Further studies on vitamin D in healthy children in Brazil are needed to establish an overview of such deficiencies ${ }^{(34,35)}$.

Vitamin D intoxication is extremely rare. In general, the reported cases are related to administration errors in supplementation (exorbitant values such as 1 million to 4 million IUs per day). The effects related to super-dose are hypercalcemia (values higher than $10.6 \mathrm{mg} / \mathrm{dL}$ ) and hyperphosphataemia (5-6 mg/dL). Therefore, supplementation is suggested with caution ${ }^{(36)}$. 
We would like to point out the need for further studies in this area to establish a consensus of what is considered vitamin D deficiency.

\section{Authors' contribution}

Contributed to conception or design: Linden MA; Freitas RGBON. Contributed to acquisition, analysis, or interpretation: Linden MA; Freitas RGBON. Drafted the manuscript: Linden MA; Freitas RGBON. Critically revised the manuscript: Linden MA; Freitas RGBON; Hessel G; Marmo DB; Bellomo-Brandão MA. Gave final approval agrees to be accountable for all aspects of work ensuring integrity and accuracy: Linden MA; Freitas RGBON; Hessel G; Marmo DB; Bellomo-Brandão MA.

\section{Orcid}

Marcela Almeida Linden. Orcid: 0000-0001-6136-8341.

Renata Germano Borges de Oliveira Nascimento Freitas. ORCID: 0000-0002-0741-0702.

Gabriel Hessel. Orcid: 0000-0002-9884-9381.

Denise Barbieri Marmo. Orcid: 0000-0001-5227-2452.

Maria Ângela Bellomo-Brandão. Orcid: 0000-0002-1145-2606.

Linden MA, Freitas RGBON, Hessel G, Marmo DB, Bellomo-Brandão MA. Definição da deficiência de vitamina D em crianças em idade escolar: revisão sistemática com metanálise. Arq Gastroenterol. 2019;56(4):425-30.

RESUMO - Contexto - A deficiência de vitamina D está sendo reconhecida como uma pandemia devido ao volume de pessoas afetadas pela deficiência e o número de doenças geradas ou estimuladas por tal deficiência. Há falta de consenso na literatura sobre o que é considerado deficiência de vitamina D [25(OH)D]. Objetivo - Esta revisão reúne os níveis mais comuns de 25(OH)D encontrados em escolares saudáveis e o que é considerado deficiência. Métodos - Esta revisão sistemática foi baseada na literatura acessada a partir das bases de dados eletrônicas: MEDLINE, EMBASE, LILACS, SCOPUS e WEB OF SCIENCE. Foram utilizados os seguintes descritores em inglês, português e espanhol: "Vitamina D"; "Deficiência de vitamina D"; "Suplementos Nutricionais", bem como todos os seus sinônimos. A meta-análise foi realizada considerando o modelo aleatório. Critérios de inclusão: crianças saudáveis na faixa etária de 6 a 12 anos, estudos que tinham níveis de vitamina D, deficiência de vitamina D definida. Resultados - Dos 191 artigos potencialmente elegíveis, apenas seis artigos foram incluídos, com 2618 escolares no total. O valor médio de 25(OH)D foi estimado em 18,11 $\mathrm{ng} / \mathrm{mL}$ com $95 \%$ de intervalo de confiança. Dentre os artigos encontrados três consideraram deficiência níveis abaixo de $20 \mathrm{ng} / \mathrm{mL}$, um considerou abaixo de $18 \mathrm{ng} / \mathrm{mL}$, outro abaixo de $15 \mathrm{ng} / \mathrm{mL}$, e o último abaixo de $11 \mathrm{ng} / \mathrm{mL}$. A prevalência da deficiência de vitamina $\mathrm{D}$ entre os artigos foi de 48,6\%,7\%,98\%, 64,63\%, 19,5\%, 28,4\%, de acordo com cada classificação utilizada por eles. Conclusão - A definição mais comum na literatura de deficiência de $25(\mathrm{OH}) \mathrm{D}$ em escolares foi em níveis inferiores a $20 \mathrm{ng} / \mathrm{mL}$. Nenhum efeito colateral foi relatado em estudos que usaram fortificação e/ou suplementação de vitamina D. A suplementação diária é mais eficaz do que a suplementação sazonal. No entanto, mais estudos são necessários para definir o que pode ser considerado como níveis ótimos de $25(\mathrm{OH}) \mathrm{D}$ em crianças.

DESCRITORES - Vitamina D. Deficiência de vitaminas. Criança. Suplementos nutricionais. Revisão.

\section{REFERENCES}

1. Hossein-nezhad A, Holick MF. Vitamin D for health: a global perspective. Mayo Clin Proc. 2013;88:720-755.

2. Holick MF. Vitamin D deficiency. N Engl J Med. 2007;357:266-81

3. Holick MF, Chen TC. Vitamin D deficiency: a worldwide problem with health consequences. Am J Clin Nutr. 2008;87:1080S-6S.

4. Fitzpatrick TB, Basset GJ, Borel P, Carrari F, DellaPenna D, Fraser PD, et al. Vitamin deficiencies in humans: can plant science help? Plant Cell. 2012;24:395-414.

5. Holick MF, Tian XQ, Allen M. Evolutionary importance for the membrane enhancement of the production of vitamin D3 in the skin of poikilothermic animals. Proc Natl Acad Sci USA. 1995;92:3124-6.

6. Holick MF, Chen TC, Lu Z, Sauter E. Vitamin D and skin physiology: a D-lightful story. J Bone Min Res. 2007;22 (Suppl 2):V28-33.

7. Holick MF. High prevalence of vitamin D inadequacy and implications for health. Mayo Clin Proc. 2006;81:353-73.

8. Okamura WH, Midland MM, Hammond MW, Abd Rahman N, Dormanen MC, Nemere I, Norman AW. Chemistry and conformation of vitamin D molecules. J Steroid Biochem Mol Biol. 1995;53:603-13.

9. Holick M, MacLaughlin J, Clark M, Holick SA, Potts JT Jr, Anderson RR, et al. Photosynthesis of previtamin D3 in human skin and the physiologic consequences. Science. 1980;210:203-5.

10. Chung M, Balk EM, Brendel M, et al. Vitamin D and calcium: a systematic review of health outcomes. Evid Rep Technol Assess (Full Rep). 2009;(183):1-420. Review.

11. Rovner AJ, Stallings VA, Kawchak DA, Schall JI, Ohene-Frempong K, Zemel BS. High risk of vitamin D deficiency in children with sickle cell disease. J Am Diet Assoc. 2008;108:1512-6.

12. Misra M, Pacaud D, Petryk A, Collett-Solberg PF, Kappy M; Drug and Therapeutics Committee of the Lawson Wilkins Pediatric Endocrine Society. Vitamin $\mathrm{D}$ deficiency in children and its management: review of current knowledge and recommendations. Pediatrics. 2008;122:398-417.
13. Holick MF. The vitamin D deficiency pandemic: Approaches for diagnosis, treatment and prevention. Rev Endocr Metab Disord. 2017;18:153-65.

14. Christakos S, DeLuca HF. Minireview: Vitamin D: is there a role in extraskeletal health? Endocrinology. 2011;152:2930-6.

15. Institute of Medicine. 2011. Dietary Reference Intakes for Calcium and Vitamin D. Washington, DC: The National Academies Press. doi:10.1542/peds. 2012-2590

16. Ross AC, Manson JE, Abrams SA, Aloia JF, Brannon PM, Clinton SK, et al. The 2011 Report on Dietary Reference Intakes for Calcium and Vitamin D from the Institute of Medicine: What Clinicians Need to Know. J Clin Endocrinol Metab. 2011;96:53-8.

17. Braegger C, Campoy C, Colomb V, Decsi T, Domellof M, Fewtrell M, et al. Vitamin D in the healthy European paediatric population. J Pediatr Gastroenterol Nutr. 2013;56:692-701.

18. Itens P, Revis R, Uma P. Principais itens para relatar Revisões sistemáticas e Meta-análises: A recomendação PRISMA. Epidemiol e Serviços Saúde. 2015;24:335-342. doi:10.5123/S1679-49742015000200017.

19. Rich-Edwards JW, Ganmaa D, Kleinman K, Sumberzul N, Holick MF, Lkhagvasuren T, et al. Randomized trial of fortified milk and supplements to raise 25-hydroxyvitamin D concentrations in schoolchildren in Mongolia. Am J Clin Nutr. 2011;94:578-84.

20. Petersen RA, Damsgaard CT, Dalskov SM, Sørensen LB, Hjorth MF, Ritz C, et al. Vitamin D status and its determinants during autumn in children at northern latitudes: a cross-sectional analysis from the optimal well-being, development and health for Danish children through a healthy New Nordic Diet (OPUS) School Meal Study. Br J Nutr. 2016;115:239-50.

21. Soininen S, Eloranta AM, Lindi V, Venäläinen T, Zaproudina N, Mahonen A, Lakka TA. Determinants of serum 25-hydroxyvitamin D concentration in Finnish children: the Physical Activity and Nutrition in Children (PANIC) study. Br J Nutr. 2016;115:1080-91 
22. Al-Ghannami SS, Sedlak E, Hussein IS, Min Y, Al-Shmmkhi SM, Al-Oufi HS, et al. Lipid-soluble nutrient status of healthy Omani school children before and after intervention with oily fish meal or re-esterified triacylglycerol fish oil. Nutrition. 2016;32:73-8

23. Mark S, Lambert M, Delvin EE, O’Loughlin J, Tremblay A, Gray-Donald K Higher vitamin D intake is needed to achieve serum $25(\mathrm{OH}) \mathrm{D}$ levels greater than $50 \mathrm{nmol} / 1$ in Quebec youth at high risk of obesity. Eur J Clin Nutr. 2011;65: 486-92.

24. Neyestani TR, Hajifaraji M, Omidvar N, Nikooyeh B, Eshraghian MR, Shariatzadeh $\mathrm{N}$, et al. Calcium-vitamin D-fortified milk is as effective on circulating bone biomarkers as fortified juice and supplement but has less acceptance: a randomised controlled school-based trial. J Hum Nutr Diet. 2014;27:606-16.

25. Weeks JP. Journal of Statistical Software. J Stat Softw. 2010;35(12).

26. Biesalski HK. Vitamin D recommendations: beyond deficiency. Ann Nutr Metab. 2011;59:10-16.

27. Whiting SJ, Calvo MS. Dietary recommendations to meet both endocrine and autocrine needs of Vitamin D. J Steroid Biochem Mol Biol. 2005;97:7-12.

28. Berlin T, Bjorkhem I. Effect of calcium intake on serum levels of 25-hydroxyvitamin D3. Eur J Clin Invest. 1988;18:52-5.
29. Thomas SD, Need AG, Nordin BE. Suppression of C-terminal telopeptide in hypovitaminosis D requires calcium as well as vitamin D. Calcif Tissue Int 2010;86:367-74.

30. Soininen S, Eloranta AM, Lindi V, Lakka TA. Response: food fortification as a means to increase vitamin D intake. Br J Nutr. 2016;116:1134-5.

31. Picciano MF. Vitamin D Status and Health. Crit Rev Food Sci Nutr. 2010;50 (Suppl 1):24-5

32. Calvo MS, Whiting SJ, Barton CN. Vitamin D fortification in the United States and Canada: current status and data needs. Am J Clin Nutr. 2004;80 (Supp 6):1710s-6s.

33. Kranz S, Lin P, Wagstaff D. Children's dairy intake in the United States: too little, too fat? J Pediatr. 2007;151:642-6.

34. Peçanha M.B., Freitas R.B., Moreira T.R., Silva L.S., Oliveira L.L., Cardoso S.A. Prevalence of vitamin D defi ciency and its relationship with factors associated with recurrent wheezing. J. Bras Pneumol. 2019;45(1).

35. Peracchi OA, Terreri MT, Munekata RV, Len CA, Sarni RO, Lazaretti-Castro M, Hilário MO Low serum concentrations of 25-hydroxyvitamin D in children and adolescents with systemic lupus erythematosus. Braz J Med Biol Res. 2014;47:721-6.

36. Holick MF. The vitamin D deficiency pandemic: Approaches for diagnosis, treatment and prevention. Rev Endocr Metab Disord. 2017;18:153-65. 